\title{
Open data platforms: Discussing alternative knowledge epistemologies
}

\author{
Lieselot Danneels \& Stijn Viaene
}

Although vast amounts of data have been opened by several levels of government around the world and high hopes continue to be expressed with respect to open data's potential for innovation, whether open government data (OGD) will live up to expectations is still questioned. Up to now, the OGD literature has focused mostly on the technical side of open data, with little focus on network aspects. We argue that a definition of what an OGD platform is, and what is within its scope, is lacking. In this exploratory article, we use three knowledge epistemologies cognitivist, connectionist, and autopoietic - as a lens to examine OGD platforms and to define three different platform types. To validate and further enrich the platform types and to identify which types are most prevalent in case study research and which are underrepresented, we performed a literature review of case studies on OGD platforms published in the main egovernment outlets between 2009 and 2016. Looking for elements of each OGD platform type in the case study literature resulted in a pressing question for more empirical research focusing on the network aspects of OGD platforms. We also highlighted the underrepresentation of the autopoietic OGD platform type in case study research. We conclude this article by providing a research agenda for OGD platforms.

Keywords: Open data, Government as a platform, Digital, Knowledge epistemology 


\section{Introduction}

The amount and the diversity of open government data (OGD) published by all levels of government worldwide continue to increase (Howard, Blanton, Holgate, Cannon \& Tratz-Ryan, 2016). In Amsterdam, as just one example of the many smart city initiatives, open data is one of the eight project focus categories, in addition to smart mobility and smart living, among others (Fitzgerald, 2016). In the Apps for Amsterdam contest, developers are challenged to build apps that re-use OGD to improve the lives of residents and visitors. Examples at the national level include Singapore, aiming to become a smart nation (Chan, 2013), and Denmark, opening up basic data about the country and its citizens to be combined and re-used by others (Jetzek, 2016). It was predicted that open data could lead to $\$ 3$ to $\$ 5$ trillion of economic value, both directly through the development of new products and services and indirectly through innovative products leading to, for example, time savings for commuters avoiding traffic delays (Manyika et al., 2013).

In the OGD literature, much has been written on the supply side, or the technological basis of open data, whereas there has been less focus on the use of open data (Maccani et al., 2015) and the ways to foster re-use (van Veenstra \& van den Broek, 2013). There are no clear definitions of what an OGD platform is, what is in scope, and whether there are different platform types. We are convinced that, even though the OGD literature is still in an early stage, there is a need for a research agenda that complements the focus on data supply with platform and network aspects.

Thus, this exploratory research aims to answer the following research questions: (1) How can we define OGD platforms, and can we define different types of OGD platforms? (2) Which elements of different OGD platform types are found in the OGD case study literature? 
To do this, we use three knowledge epistemologies - cognitivist, connectionist, and autopoietic as a lens. We are convinced that this a useful and interesting lens to look at OGD platforms, which can be considered a special form of knowledge system. By reinterpreting the knowledge epistemologies for OGD platforms, we define three platform types. To validate and further enrich the platform types, we perform a literature review that looks for elements of each type in OGD case studies published in the main e-government outlets (Scholl \& Dwivedi, 2014) between 2009 and 2016. Although looking at the cases through the lens of the author brings some limitations, this review validates the applicability of the platform types to OGD case studies and indicates the focus of the OGD case studies. From this literature review, we are able to identify which platform types are most prevalent and which ones are underrepresented. Therefore, the literature review also gives rise to a research agenda.

Our first contribution is the introduction of three types of OGD platforms. A second contribution is that we explore, through empirical examples from the literature review, how the platform types lead to different foci for research on OGD platforms. We find that one of the types of OGD platforms, the autopoietic platform type, is underrepresented in the literature. Therefore, a third contribution is the development of a research agenda.

This paper is structured as follows. Section 2 draws lessons for OGD platforms from the platform literature. Section 3 introduces the knowledge epistemologies that will be reinterpreted to define the different OGD platform types. Section 4 explains the methodology used for the literature review. Section 5 provides descriptive statistics on the results from the literature review. Section 6 presents the data analysis and discussion. Section 7 provides a synthesis and research agenda for OGD platforms. Section 8 closes the article with conclusions and issues for further research. 


\section{Towards a definition of OGD platform types}

\section{$2.1 O G D$}

Ideally, open data is available online under an open license, in a structured, non-proprietary open format, using URIs, and linked to other data (Tim Berners-Lee, 2010). If open data is government-related data opened to the public (Kucera, Chlapek \& Necasky, 2013), it is called open government data (OGD). There are three main approaches to OGD: transparency, accountability, and innovation (Attard et al., 2015). We focus on the innovation approach, which concentrates on fostering re-use of open data to develop new services.

The evolution of OGD initiatives and the corresponding OGD literature have been amply documented (Attard et al., 2015; Maccani et al., 2015; Thorsby et al., 2017). In broad terms, the OGD literature started with defining basic concepts focused on the data but has evolved towards also taking external factors into account, opening up towards the entire OGD life cycle and including assessments and evaluations (Attard et al., 2015). However, up to now, the focus has mainly been on the supply of open data or how to make open data available (Attard et al., 2015; Maccani et al., 2015), rather than how to build something useful with it or how to foster re-use or build strategic partnerships. At the same time, van Veenstra and van den Broeck (2013) stress that, especially for later phases in the process of opening up data, the ways to foster re-use and build strategic partnerships become more important.

Several authors have expressed high hopes for OGD to transform government. O'Reilly (2011) was among the first to envision government as a digital platform, where government is "a convener and enabler rather than the first mover of civic action”. O'Reilly identified the open data movement as one of the most promising forces driving this vision forward. His proposition 
was rooted in the belief that if the government realizes that it can be a digital platform provider, albeit a developing one, it might make radically different management choices (see, e.g., Danneels \& Viaene, 2015). The enthusiasm around OGD by open data visionaries such as O'Reilly (2011) gave rise to many open data initiatives around the world, but it has been adjusted to a reality characterized by many barriers hindering the process of opening up (Huijboom \& Van den Broek, 2011; Van Veenstra \& Van den Broek, 2013; Zuiderwijk et al., 2012a, 2012b). As a result, more recent visions on how OGD can transform government take an ecosystem view, taking the complex interactions between many actors into account. According to the ecosystem approach, open data re-use does not automatically follow as a logical next step from open data publication, and the re-use of open data needs to be consciously fostered. An example of the ecosystem approach can be found in Harrison et al. (2012), who want to see government evolve towards "information age networked and interdependent systems". This view is also supported by Janssen and Estevez (2013), who refer to government as the orchestrator of a complex network of collaborative entities and see technological platforms as a key enabler. In the same vein, Brown et al. (2014) argue for a transition to "a new, diverse ecosystem of state, private and third sector activity, organized around the citizen in the form of services."

\subsection{OGD platforms}

Contrary to most of the open data literature (Thorsby et al., 2017), our definition of an OGD platform is broader than only the data portal or datasets; it also includes the actors and the (results of the) use of the data. Gawer's (2014) definition of a platform combines this focus on both technological elements and network aspects. She defined technological platforms as "evolving organizations or meta-organizations that: (1) federate and coordinate constitutive

agents who can innovate and compete; (2) create value by generating and harnessing economies 
of scope in supply or/and in demand; and (3) entail a modular technological architecture composed of a core and a periphery". Similarly, OGD platforms consist of a core of OGD and a periphery of APIs, apps resulting from open data re-use, and even other (linked) data, tools, and services. OGD platforms create value by generating economies of scope in innovation and lower the cost of innovating by re-using OGD. An essential part of the OGD platform for generating value is the evolving network of actors surrounding it (e.g., the third-party developers, the platform's partners and users). This network can be orchestrated by a central organization (government) or a combination of organizations. We define an OGD platform as "an architecture

of data services together with the governance of access and (re-)use, created for the purpose of allowing third parties to create new value". Government's role consists of enabling and facilitating productive value creation by leading the architecture and governance design decisions. This does not automatically imply, however, that solely government makes these decisions; it depends on the degree of openness of the design.

\subsection{Platform types}

Several authors have proposed unifying frameworks of platforms, defining different platform types (Gawer, 2014; Henderson, Kulatilaka, Venkatraman \& Freedman, 2014). Gawer (2014) bridged information systems and economic literature in her framework distinguishing between internal platforms, supply-chain platforms and industry-platforms. The platform types distinguished in the framework require different management and governance practices and thus different research focuses as well. The identification of different platform types is based on an exogenous variable, such as the organizational form (Gawer, 2014). Henderson et al. (2014) distinguish between three platform types (an intra-firm technology platform, inter-firm capability 
platform and ubiquitous business platform), based on the potential scope of impact enabled by technological innovation.

Much of the OGD literature has focused on the technical side of OGD platforms, or on open data supply (Attard, Orlandi, Scerri \& Auer 2015; Maccani et al., 2015), but to our knowledge, no research has been performed on defining different types of OGD platforms. OGD platforms are still a rather new phenomenon, and compared to technological platforms, there are no separate literature streams studying it. Still, we can learn from the platform literature to make a distinction between different types of OGD platforms requiring a different management and governance approach and different research focus.

To define OGD platform types, it is necessary to determine which distinguishing exogenous variable defines the difference between the types. The openness of the platform and the accessible innovative capabilities from Gawer's (2014) framework provide no exogenous variables for OGD platforms, which are by default characterized by their openness. The evolving scope of potential impact of Henderson et al. (2014) does not qualify as a distinguishing feature either, because OGD platforms are open by default. A key barrier to bridging the different views on OGD platforms may lie in their definitions of knowledge and knowledge management. Different OGD platforms types should therefore not impose the same knowledge management view. Rather, a distinction of different platform types would present OGD platforms in the diverse ways in which they foster the generation of new value and highlight their essential characteristics. 


\section{Knowledge epistemologies as a lens}

This article takes knowledge epistemologies as a lens to propose different OGD platform types. Each platform type uses different definitions of knowledge and knowledge management. In this section, we first provide an overview of three knowledge epistemologies (cognitivist, connectionist, and autopoietic), which we then reinterpret for OGD platforms.

\subsection{Knowledge epistemologies}

Knowledge epistemologies are defined as basic assumptions about knowledge on which the addressed concepts and theories are based and vary in their perceptions of the notion of knowledge and the management and development of knowledge (Von Krogh \& Roos, 1995). See Table 1.

Table 1. Knowledge epistemologies (based on Skok \& Kalmanovitch, 2005; Venzin, von Krogh \& Roos, 1998)

\begin{tabular}{|c|c|c|c|}
\hline & Cognitivist & Connectionist & Autopoietic \\
\hline $\begin{array}{l}\text { Notion of } \\
\text { knowledge }\end{array}$ & $\begin{array}{l}\text { Knowledge is a fixed and } \\
\text { representable entity that } \\
\text { can be stored in computers, } \\
\text { databases, archives and is } \\
\text { easily shared }\end{array}$ & $\begin{array}{l}\text { Knowledge can exist only } \\
\text { through the connections of } \\
\text { experts; it is problem-- } \\
\text { solution orientated and } \\
\text { dependent upon those } \\
\text { connections }\end{array}$ & $\begin{array}{l}\text { Knowledge is part of a } \\
\text { social system; it is } \\
\text { observer/history } \\
\text { dependent, context } \\
\text { sensitive and not directly } \\
\text { shared, only indirectly } \\
\text { through discussions }\end{array}$ \\
\hline $\begin{array}{l}\text { Management and } \\
\text { development of } \\
\text { knowledge }\end{array}$ & $\begin{array}{l}\text { Standardized management } \\
\text { of information }\end{array}$ & $\begin{array}{l}\text { Management of } \\
\text { standardized information } \\
\text { through communities }\end{array}$ & $\begin{array}{l}\text { Management of data } \\
\text { through individual people }\end{array}$ \\
\hline
\end{tabular}

Cognitivist approaches equate knowledge with information and data and thus believe that no further interpretation is necessary (von Krogh \& Roos, 1995). Representationalism is a fundamental part of the cognitivist epistemology: the world is pre-defined and can be fully discovered and represented by the human mind or by an organization (Rorty, 1980). Learning is therefore the increasingly accurate definition of representation corresponding to the external 
world (Bruner \& Anglin, 1973). People and organizations are transparent to information from the outside and have the ability to process this information (Rorty, 1980). They behave like machines or computers and use logic and probability judgments to come up with internally consistent propositions (Varela, 1992). A knowledge management tool is used to acquire, store and disseminate information (Skok \& Kalmanovitch, 2005).

The connectionist epistemology believes that many of the rules of how to process information are not universal but vary locally (von Krogh \& Roos, 1995). Relationships and communication are the most important elements of the cognitivist epistemology (Varela, Thompson \& Rosch, 1992). Knowledge emerges and resides not only in the brains of each organizational member but also in the connections among members through the rules of heedful interrelating: each member knows what needs to be done in relation to what the others are doing (Weick \& Roberts, 1993). A knowledge management tool not only is used to acquire, store and disseminate information but also assists in making the right connections between different groups (Skok \& Kalmanovitch, 2005).

In the autopoietic epistemology, knowledge cannot be directly conveyed from one individual to another, because data have to be interpreted (Venzin, von Krogh \& Roos, 1998). Knowledge management systems are "created in an autonomous, simultaneously open and closed, selfreferencing, and observing manner" (von Krogh \& Roos, 1995). Autopoietic systems are often explained as biological cells, or autonomous entities that are able to constantly renew themselves: "components of the cell produce other components which produce the units that produced them" (Maturana \& Varela, 1980). Knowledge management systems are seen as a living organism rather than a machine for processing information. Employees are free to use the knowledge management system or not, but the organization provides incentives for doing so and 
supports employees in pursuing new opportunities (Nonaka \& Takeuchi, 1995). The environment and the knowledge management system are co-evolving. The process of interpreting incoming data in conversations is the cornerstone of knowledge development (Skok \& Kalmanovitch, 2005). Positive feedback loops ensure that new additions to the knowledge management system enable the autopoietic system to make further observations, which in turn leads to new additions to the system (Venzin, et al., 1998).

\subsection{Differing views on OGD platforms}

We reinterpreted the knowledge epistemologies for OGD platforms, a specific form of knowledge systems. By starting from the knowledge epistemologies, we were able to develop an informed argumentation for the three OGD platform types. Figure 1 compares the OGD platform, the actors, and their interrelationships according to each knowledge epistemology.

The cognitivist epistemology considers OGD platforms as neutral tools for disseminating information. In the cognitivist view, open data should be organized for ad hoc querying by, typically, individual actors. The focus is limited to the interactions between the actor re-using the data and the data themselves. The direction of this interaction is one-way. An example of a cognitivist OGD platform is an open data portal listing several types of datasets. The governance of the platform is rather limited in scope: the government ensures that the platform is open towards third parties and does not actively stimulate re-use.

In the connectionist epistemology, the government uses its data to foster connections between other platform actors and actively stimulates this. The aim is not simply combining datasets or making a connection between a platform actor and the data. Instead, the main focus is on connecting actors who otherwise would not necessarily collaborate to re-use open data. Although 
the OGD platform is an important enabler for this collaboration, the collaboration itself or results from OGD re-use are typically not visible on the platform. An example of a connectionist OGD platform is an open data portal listing several types of datasets, with certain parts of the platform focused on specific themes of interest, supported by offline hackathon events focused on bringing third parties together around these specific themes. In the governance of the platform, the government focuses on stimulating new value creation through the re-use of OGD by connecting third parties to each other.

Using the autopoietic knowledge epistemology implies looking at OGD platforms as living organisms rather than as machines for processing information. Feedback loops are the basis for a learning platform, which is reflected in the two-directional relationship arrows in Figure 1. An example of an autopoietic OGD platform is an open data portal listing several types of datasets from several sources (not only government) but also consisting of other tools and services that are useful in re-using the data and even results from the re-use (links to the apps, as well as new data resulting from the use of the apps). Hackathons are just one of the many ways to stimulate re-use, which all contribute to further enriching the open data portal. Governing the autopoietic platform requires important trade-offs to be made, balancing control over the platform and over the new value created with ways to stimulate more variety.

An important difference with the connectionist view is that actors remain on the platform and the re-use of OGD further enriches the platform. In the autopoietic view, OGD platforms are dynamic, self-renewing ecosystems, co-evolving with the environment. A central concept in the ecosystem literature is resilience: technology ecosystems need to be simultaneously stable, to assure ecosystem actors that their investments can yield long-term results, and evolvable, to adjust to changes (Wareham, Fox \& Cano Giner, 2014). Therefore, the design of governance 
mechanisms for an autopoietic OGD platform is not an easy task: the main challenge is balancing this "paradox of change" (Tilson, Lyytinen \& Sorenson, 2010). An ecosystem keystone uses governance mechanisms that go beyond the mere publishing and distribution of OGD, instead forming a strategy that purposefully orchestrates an ecosystem of complementors (Tilson et al., 2010; Wareham et al., 2014). The orchestration role of the ecosystem keystone consists of two essential parts (Iansiti \& Levien, 2004). The first is creating value by offering essential services, tools, or technologies that provide solutions to others in the ecosystem (in a more or less open way). For an OGD platform, this is the case by definition, and this part of the keystone role is covered in all three OGD platform types. Second, the keystone has to foster the health of the ecosystem by making sure that ecosystem parties want to join and remain around the table. Whereas in the connectionist OGD platform, the focus is making sure that third parties join, it is only in the autopoietic OGD platform type that all parts of the keystone role are fully covered. In an autopoietic platform or ecosystem, catering to ecosystem health implies a focus on ecosystem productivity, robustness and meaningful diversity. Productivity is increased by simplifying the complex task of connecting new participants to one another and by making the creation of new products by third parties more efficient. Robustness is guaranteed by consistently incorporating technological innovations and by providing a reliable point of reference that helps participants respond to new and uncertain conditions. The creation of meaningful diversity, contributing to the productivity and robustness of the system, is stimulated by offering innovative technologies to a variety of third parties. 
Figure 1. OGD platforms according to the knowledge epistemologies

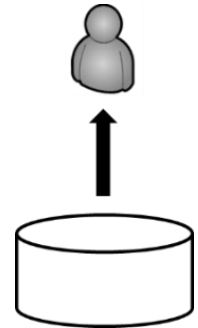

Cognitivist

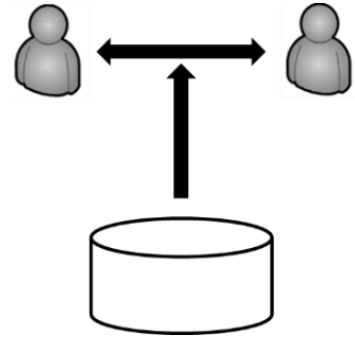

Connectionistic

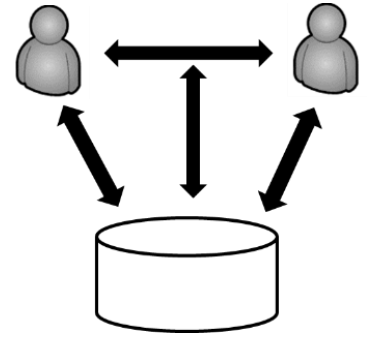

Autopoietic

\subsection{Repurposing knowledge epistemologies for OGD platforms}

We repurposed and reinterpreted the knowledge epistemologies as a lens to propose different types of OGD platforms. This implies a broadening of the scope of the knowledge epistemologies towards a network of actors, compared to their original focus on a single organization (Von Krogh \& Roos, 1995).

The three epistemologies, reciprocally, also present a difference in scope with respect to the role of government. In the cognitivist epistemology, the government's role ends when the data are opened on a platform. In the connectionist epistemology, the government also aims to stimulate the re-use of OGD by fostering connections between different actors. In the autopoietic epistemology, the government becomes the orchestrater of the ecosystem platform.

The three epistemologies represent an evolution: each epistemology has characteristics that are similar to the preceding one but adds some important distinctive characteristics as well. The original knowledge epistemologies were already represented as a continuum, and technology keeps evolving towards more autopoietic forms. Still, our purpose is not to promote the autopoietic epistemology as the best option, regardless of the context. Although at best, the 
autopoietic epistemology might have the greatest potential to activate the entire innovation network, this will not always be possible or even preferable. The choice of any type of OGD platform depends on a government's objectives, resources, and context. It is key for the government to at least be aware of the different types of OGD platforms, as familiarity with the different types means having a better understanding of the limitations of each approach. The realization that others might strive for another type of OGD platform will decrease misunderstandings. The conscious choice of an OGD platform type is a critical success factor for research and for practitioners; therefore, moving from one platform type to another should be a mindful decision.

\section{Methodology}

We performed a literature review to validate and further enrich the OGD platform types that we proposed based on the differing knowledge management views. We were also looking for an indication of which types were most prevalent in the literature and which ones were underrepresented. Our aim was to look for signals or elements of the different OGD platform types, rather than to give an exhaustive summary of open data research.

To conduct the literature review, we followed the approach proposed by Information Systems (IS) researchers (Levy \& Ellis, 2006; Webster \& Watson, 2002). We selected articles published between 2009 and 2016. We focused on the main forums for electronic government scholars, both first tier and second tier, as identified by Scholl and Dwivedi (2014). We reviewed both conference proceedings and journals, which have equal standing in the domain (Scholl \& Dwivedi, 2014). We were looking for practical examples of open data platforms rather than theoretical or context-unaware suggestions for practice. A quick first scan of the literature on 
OGD confirmed that many practical examples occur at the local level. This is not unexpected given that smart cities are a popular and widely employed concept (see, e.g., Van den Bergh \& Viaene, 2016) in which proximity to the citizens may ease practical applications of open data.

The literature review was an iterative process during which we reviewed references to search for other sources to be included. Based on this iterative review, we extended the list of relevant sources with two extra journals: Technological Forecasting and Social Change, and Journal of the Knowledge Economy. We included these journals as they are some of the only outlets for smart city literature.

As a result, we reviewed 24 sources: 16 journals and 8 conferences. For a more detailed overview, we refer to Table 2 .

Table 2. Selected journals and conferences

\section{Journals}

Government Information Quarterly (GIQ)

Public Administration Review (PAR)

Journal of Public Administration Research and Theory (JPART)

Information Polity (IP)

Journal of Information Technology and Politics (JITP)

Transforming Government: People, Process and Policy (TGPPP)

International Journal of Electronic Government Research (IJEGR)

European Journal of Information Systems (EJIS)

Management Information Systems Quarterly (MISQ)

Administrative Science Quarterly (ASQ)

Journal of the AIS (JAIS)

International Journal of Public Administration (IJPA)

International Journal of Electronic Governance (IJEG)

Information Systems Journal (ISJ)

Technological Forecasting and Social Change (Technol Forecast Soc)

Journal of the Knowledge Economy (J Knowl Econ)

\section{Conferences}

Hawaii International Conference on System Sciences (HICSS)

IFIP Electronic Government (IFIP EGOV)

International Conference on Digital

Government Research (dg.o)

European Conference on Information Systems (ECIS)

IFIP Electronic Participation (IFIP EPART)

European Conference on e-Government (ECEG)

International Conference on Theory and Practice of Electronic Government (ICEGOV)

Americas Conference on Information Systems (AMCIS) 
Because of our empirical focus, we looked for combinations of "open data" AND "case study" or "open data" AND "smart city" in the title, abstract or text of the reviewed articles. We added the term "government" for the IS journals, which do not specifically focus on e-government. The keywords were kept broad on purpose as we expected to see a variety of cases, instead of focusing only on open data portals, hackathons, or smart cities.

The preliminary search resulted in 146 articles. The criteria for refining the preliminary set of articles were defined upfront by two of the authors, and they were further refined during three iterative review rounds. From the preliminary search result, we selected articles of more than four pages, limiting the preliminary result to a set of 127 articles. Six more articles were excluded by eliminating book reviews, editorials, introductions to special issues and descriptions of planned research. By reading the full articles, we removed those articles of which open data was not the main focus. Some articles mentioned only open data once; others took a governmentinternal perspective and dealt only with inter-agency sharing of data or data reporting between one specific industry and government. This resulted in the elimination of 45 articles.

From the remaining 76 articles, we selected those presenting a case study of open data in government, although not necessarily presented from the government's perspective. It was not enough to present a use case merely to illustrate a theoretical proposition or model or to purely discuss open data gathering, open data publishing, or how the decision was made about whether to open data. Rather, we were looking for rich, practical case reports on open data re-use relating to our research questions. Finally, we arrived at a selection of 35 articles.

After the selection of the articles, two of the authors independently looked for cognitivist, connectionist or autopoietic elements in the case studies, based on the description of the epistemologies in section 3. During two consecutive discussion moments, they reviewed the 
mapping of the elements for inconsistencies. These were discussed until an agreed-upon mapping was reached, which in turn resulted in a further refinement of the entire mapping process. Where possible, we focused on the reality of the case study rather than aspirations for the future, because we wanted to bring the vision for OGD platforms back to a practical level.

\section{Descriptive statistics}

Table 3 provides an overview of the case study topic, the research question, the level of government studied, and whether the article used primary data $(\mathrm{P})$, secondary data $(\mathrm{S})$, or both (P/S). Most articles used primary data sources: 12 articles used primary data only, 16 more used a combination of primary and secondary data, and only 7 articles relied on secondary data only. The case studies show different government levels, but a vast majority of the 19 cases are situated at the local level. 8 articles present cases at the national level, 1 presents a case at the regional level, and 2 present cases at supra-national level. One study could not be classified because it focused on hackers using a broad range of open data platforms. The remaining 4 articles either present a case taking place at multiple levels or several cases at different levels. 
Table 3. Overview of open data case studies

\begin{tabular}{|c|c|c|c|c|c|}
\hline Authors & Outlet & Case study topic & Research question & Level & Data \\
\hline $\begin{array}{l}\text { AlAwadhi \& } \\
\text { Scholl, } 2013\end{array}$ & HICSS & Seattle & $\begin{array}{l}\text { "How do city officials define a "smart city"? [...] What are actual smart city } \\
\text { projects and initiatives about and how do they match up with these definitions of } \\
\text { "smart city"? }\end{array}$ & Local & $P$ \\
\hline $\begin{array}{l}\text { Bakici et al., } \\
2013\end{array}$ & $\begin{array}{l}\text { J Knowl } \\
\text { Econ }\end{array}$ & Barcelona & $\begin{array}{l}\text { "(1) How does city hall manage transformation? (2) What are the underlying } \\
\text { drivers and bottlenecks for transformation? (3) What are the main obstacles } \\
\text { faced by the city hall? (4) What are the necessary conditions to be established for } \\
\text { the transformation? (5) What are the assets/infrastructures required to become a } \\
\text { Smart City?" }\end{array}$ & Local & $\mathrm{P} / \mathrm{S}$ \\
\hline $\begin{array}{l}\text { Bertot et al., } \\
2014\end{array}$ & Dg.o & $\begin{array}{l}\text { Medium-sized US } \\
\text { city }\end{array}$ & $\begin{array}{l}\text { "What are the local data needs of community organizations, libraries, and other } \\
\text { community stakeholders? How do these stakeholders identify and select data of } \\
\text { interest? How do these stakeholders currently manage the data that they use? } \\
\text { Are there data that would be of use but are currently out of the reach of these } \\
\text { stakeholders? How are these stakeholders using community data, and what are } \\
\text { the gaps in skills regarding data use? What roles can libraries play in the } \\
\text { collection, management, and use of data within local communities? What } \\
\text { challenges do libraries face in assuming data infrastructure roles in their } \\
\text { communities?" }\end{array}$ & Local & $\mathrm{P} / \mathrm{S}$ \\
\hline Chan, 2013 & HICSS & Singapore & $\begin{array}{l}\text { "What are open innovation strategies for creating an open innovation platform } \\
\text { and enticing participation?" }\end{array}$ & National & $\mathrm{S}$ \\
\hline $\begin{array}{l}\text { Dawes et al., } \\
2016\end{array}$ & GIQ & $\begin{array}{l}\text { New York and St. } \\
\text { Petersburg }\end{array}$ & $\begin{array}{l}\text { "How can a given government's open data program stimulate and support an } \\
\text { ecosystem of data producers, innovators, and users? In what ways and for whom } \\
\text { do these ecosystems produce benefits? Can an ecosystem approach help } \\
\text { governments design effective open government data programs in diverse } \\
\text { cultures and settings? }\end{array}$ & Local & $\mathrm{P} / \mathrm{S}$ \\
\hline $\begin{array}{l}\text { Effing \& Groot, } \\
2016\end{array}$ & $\begin{array}{l}\text { IFIP } \\
\text { EGOV }\end{array}$ & Berlin & $\begin{array}{l}\text { "By using what digital strategies can cities effectively involve citizens and } \\
\text { companies in the policy and development process of the city in order to become a } \\
\text { smarter city?" }\end{array}$ & Local & $\mathrm{S}$ \\
\hline Elbadawi, 2012 & ECEG & $\begin{array}{l}\text { Bahrain, Saudi } \\
\text { Arabia and United } \\
\text { Arab Emirates }\end{array}$ & $\begin{array}{l}\text { "What are the key driving forces for opening up government in these countries? } \\
\text { What approach did each country follow to initiate and manage its OGD } \\
\text { initiative? What are the key challenges facing the OGD initiative in each country? } \\
\text { What are the plans to overcome them? How does each of these countries } \\
\text { perceive the OGP, in light of their local priorities and practices? How will these } \\
\text { countries sustain and enrich their OGD practices in the future?" }\end{array}$ & National & $\mathrm{P} / \mathrm{S}$ \\
\hline $\begin{array}{l}\text { Gonzalez-Zapata } \\
\text { \& Heeks, } 2015\end{array}$ & GIQ & $\begin{array}{l}\text { OGD stakeholders in } \\
\text { Chile }\end{array}$ & $\begin{array}{l}\text { "What are the multiple meanings ascribed to open government data?" The } \\
\text { authors further divide this into three sub-questions: "Who are the different } \\
\text { stakeholders shaping the meaning of OGD in this context? What are the different }\end{array}$ & National & $\mathrm{P} / \mathrm{S}$ \\
\hline
\end{tabular}




\begin{tabular}{|c|c|c|c|c|c|}
\hline & & & $\begin{array}{l}\text { meanings these stakeholders give to OGD in this context? Why are the different } \\
\text { stakeholders ascribing these particular meanings?" }\end{array}$ & & \\
\hline $\begin{array}{l}\text { Hellberg \& } \\
\text { Hedström, } 2015\end{array}$ & TGPPP & $\begin{array}{l}\text { Innovation } \\
\text { competition in a } \\
\text { Swedish municipality }\end{array}$ & $\begin{array}{l}\text { What are "the challenges of organizing an innovation competition for promoting } \\
\text { citizen re-use of open public data?" }\end{array}$ & Local & $\mathrm{P}$ \\
\hline $\begin{array}{l}\text { Hielkema \& } \\
\text { Hongisto, } 2013\end{array}$ & $\begin{array}{l}\text { J Knowl } \\
\text { Econ }\end{array}$ & Helsinki & $\begin{array}{l}\text { "How can Mobile Application Clusters be developed through competitions for } \\
\text { innovative applications?" }\end{array}$ & $\begin{array}{l}\text { Local and } \\
\text { regional }\end{array}$ & $\mathrm{S}$ \\
\hline $\begin{array}{l}\text { Hjalmarsson et } \\
\text { al., } 2014\end{array}$ & ECIS & $\begin{array}{l}\text { Travelhack in } \\
\text { Stockholm, Sweden }\end{array}$ & $\begin{array}{l}\text { "What barriers inhibit the development of viable digital services from prototypes } \\
\text { generated at digital innovation contests?" }\end{array}$ & Local & $\mathrm{P}$ \\
\hline $\begin{array}{l}\text { Hjalmarsson et } \\
\text { al., 2015a }\end{array}$ & HICSS & $\begin{array}{l}\text { Transport and } \\
\text { accessibility project } \\
\text { in North Sea } \\
\text { European region }\end{array}$ & $\begin{array}{l}\text { "How can different open data stakeholders benefit from performing systematic } \\
\text { open data assessment?" }\end{array}$ & Supra-national & $\mathrm{P}$ \\
\hline $\begin{array}{l}\text { Hjalmarsson et } \\
\text { al., 2015b }\end{array}$ & ECIS & $\begin{array}{l}\text { Travelhack in } \\
\text { Stockholm, Sweden }\end{array}$ & $\begin{array}{l}\text { "What innovation barriers constrain third party developers in different phases } \\
\text { when performing open data service development after innovation contests?" }\end{array}$ & Local & $\mathrm{P}$ \\
\hline Hu et al., 2016 & Dg.o & Shenzen & "How to prepare an open data program?" & Local & $\mathrm{P} / \mathrm{S}$ \\
\hline $\begin{array}{l}\text { Huntgeburth \& } \\
\text { Veit, } 2013\end{array}$ & ECIS & German University & $\begin{array}{l}\text { Is there a "bias in favor of implementing Open Government"? What are "the } \\
\text { consequences of implementing an Open Government initiative"? }\end{array}$ & Local & $\mathrm{P} / \mathrm{S}$ \\
\hline $\begin{array}{l}\text { Janssen et al., } \\
2015\end{array}$ & $\begin{array}{l}\text { IFIP } \\
\text { EGOV }\end{array}$ & $\begin{array}{l}\text { Smart energy } \\
\text { (Amsterdam), Smart } \\
\text { mobility (Rio de } \\
\text { Janeiro) }\end{array}$ & $\begin{array}{l}\text { What is "the complementariness of smart cities and big and Open Data research } \\
\text { streams"? }\end{array}$ & Local & $\mathrm{P} / \mathrm{S}$ \\
\hline Jetzek, 2016 & GIQ & $\begin{array}{l}\text { Danish Basic Data } \\
\text { Program }\end{array}$ & $\begin{array}{l}\text { "How can the tensions in a multi-stakeholder open data infrastructure } \\
\text { implementation be addressed through governance strategies?" }\end{array}$ & National & $\mathrm{P} / \mathrm{S}$ \\
\hline $\begin{array}{l}\text { Juell-Skielse et } \\
\text { al., } 2014\end{array}$ & $\begin{array}{l}\text { IFIP } \\
\text { EGOV }\end{array}$ & $\begin{array}{l}\text { Travelhack in } \\
\text { Stockholm, Sweden }\end{array}$ & What is "the motivation for the public to engage in innovation on open data"? & Local & $\mathrm{P}$ \\
\hline Kassen, 2013 & GIQ & Chicago & $\begin{array}{l}\text { What is "the empowering potential of the open data phenomenon in the Chicago } \\
\text { area as a platform useful for promotion of civic engagement projects at the local } \\
\text { level"? }\end{array}$ & Local & $\mathrm{S}$ \\
\hline $\begin{array}{l}\text { Klievink et al., } \\
2014\end{array}$ & $\begin{array}{l}\text { IFIP } \\
\text { EGOV }\end{array}$ & $\begin{array}{l}\text { European open } \\
\text { government data }\end{array}$ & $\begin{array}{l}\text { What are "common and differing elements in the IIs [Information } \\
\text { Infrastructures] and their impact"? }\end{array}$ & Supra-national & $\mathrm{P} / \mathrm{S}$ \\
\hline $\begin{array}{l}\text { Kuk \& Davies, } \\
2011\end{array}$ & ICIS & $\begin{array}{l}\text { Open data hackers in } \\
\text { the UK }\end{array}$ & $\begin{array}{l}\text { What are the "processes involved in the use of open data, and the enabling and } \\
\text { limiting factors for the creation of sustainable service innovation based on open } \\
\text { data"? } \\
\text { "How [does] the accumulation of artifacts, and the agency of developers, impact } \\
\text { on sustainable open data re-use"? }\end{array}$ & NA & $\mathrm{P} / \mathrm{S}$ \\
\hline
\end{tabular}




\begin{tabular}{|c|c|c|c|c|c|}
\hline Lee et al., 2014 & $\begin{array}{l}\text { Technol } \\
\text { Forecast } \\
\text { Soc }\end{array}$ & $\begin{array}{l}\text { Seoul and San } \\
\text { Francisco }\end{array}$ & $\begin{array}{l}\text { What are "the opportunities offered and challenges posed to different } \\
\text { stakeholders in the smart city, including central government officials, city } \\
\text { representatives, and private sector players"? }\end{array}$ & Local & $\mathrm{P} / \mathrm{S}$ \\
\hline $\begin{array}{l}\text { Lindmann et al., } \\
2014\end{array}$ & HICSS & $\begin{array}{l}14 \text { Finnish } \\
\text { organizations }\end{array}$ & $\begin{array}{l}\text { "What are the actors and their positions in the emerging value network?" "Which } \\
\text { business and revenue models are utilized by the early open data entrepreneurs?" }\end{array}$ & National & $\mathrm{P}$ \\
\hline $\begin{array}{l}\text { Maccani et al., } \\
2015\end{array}$ & ECIS & $\begin{array}{l}\text { Company turning } \\
\text { open datasets into } \\
\text { services }\end{array}$ & $\begin{array}{l}\text { "What are the factors that influence the diffusion of open data for new service } \\
\text { development?" }\end{array}$ & Local & $\mathrm{P}$ \\
\hline $\begin{array}{l}\text { Maruyama et al., } \\
2013\end{array}$ & HICSS & $\begin{array}{l}\text { Collaboration } \\
\text { between Code for } \\
\text { America and city }\end{array}$ & $\begin{array}{l}\text { What is the "usefulness of a diplomatic design approach" in the open data } \\
\text { movement? }\end{array}$ & Local & $\mathrm{P} / \mathrm{S}$ \\
\hline $\begin{array}{l}\text { Matheus \& } \\
\text { Janssen, } 2016\end{array}$ & Dg.o & $\begin{array}{l}\text { Transparency and } \\
\text { OGD portals in Brazil }\end{array}$ & What are "strategies for public organizations to become ambidextrous"? & $\begin{array}{l}\text { National/ } \\
\text { Regional/Local }\end{array}$ & $\mathrm{S}$ \\
\hline $\begin{array}{l}\text { Neuroni et al., } \\
2013\end{array}$ & HICSS & $\begin{array}{l}\text { Zurich and } \\
\text { Switzerland }\end{array}$ & $\begin{array}{l}\text { "What are the main OGD goals in Switzerland from a leadership perspective, } \\
\text { considering that transparency and participation are already at a satisfactory } \\
\text { level?" }\end{array}$ & $\begin{array}{l}\text { Local and } \\
\text { national }\end{array}$ & $\mathrm{P}$ \\
\hline Ojo et al., 2015 & HICSS & $\begin{array}{l}\text { Barcelona, Chicago, } \\
\text { Manchester, } \\
\text { Amsterdam and } \\
\text { Helsinki }\end{array}$ & $\begin{array}{l}\text { "How [are] open data initiatives [...] shaped by the different smart cities contexts } \\
\text { and concomitantly what kinds of innovations are enabled by open data in these } \\
\text { cities?" }\end{array}$ & Local & $\mathrm{S}$ \\
\hline $\begin{array}{l}\text { Reggi \& Dawes, } \\
2016\end{array}$ & $\begin{array}{l}\text { IFIP } \\
\text { EGOV }\end{array}$ & $\begin{array}{l}\text { OpenCoesione in } \\
\text { Italy }\end{array}$ & $\begin{array}{l}\text { Does the research stream focusing on OGD for purposes of innovation interact } \\
\text { with the stream focusing on participation and accountability, and how? }\end{array}$ & National & $\mathrm{P} / \mathrm{S}$ \\
\hline $\begin{array}{l}\text { Rudmark et al., } \\
2012\end{array}$ & ECIS & $\begin{array}{l}\text { Stockholm public } \\
\text { transport company }\end{array}$ & How are "co-creation activities motivated and driven"? & Local & $\mathrm{P}$ \\
\hline $\begin{array}{l}\text { Smith et al., } \\
2016\end{array}$ & HICSS & $\begin{array}{l}\text { Trafiklab, Swedish } \\
\text { open public } \\
\text { transport data } \\
\text { marketplace }\end{array}$ & "How do open data marketplaces generate value for open data users?" & Regional & $\mathrm{P} / \mathrm{S}$ \\
\hline $\begin{array}{l}\text { Styrin et al., } \\
2016\end{array}$ & Dg.o & $\begin{array}{l}\text { OGD in Mexico, } \\
\text { Russia and the US }\end{array}$ & $\begin{array}{l}\text { "How are variations in OG and OGD policies related to context-specific historical } \\
\text { problems, policies and politics? [...] How do these information policies evolve } \\
\text { from initial interest, expressed perhaps as a focus of the executive, towards } \\
\text { sustained and institutionalized practice? }\end{array}$ & National & $\mathrm{S}$ \\
\hline $\begin{array}{l}\text { Susha et al., } \\
2015\end{array}$ & TGPPP & $\begin{array}{l}4 \text { case studies on } \\
\text { statistical agencies } \\
\text { and municipalities, } \\
\text { in The Netherlands } \\
\text { and Sweden }\end{array}$ & "Which organizational measures can facilitate the use of open data"? & $\begin{array}{l}\text { Local and } \\
\text { national }\end{array}$ & $\mathrm{P} / \mathrm{S}$ \\
\hline
\end{tabular}




\begin{tabular}{|c|c|c|c|c|c|}
\hline $\begin{array}{l}\text { Valja \& Ladhe, } \\
2015\end{array}$ & HICSS & Stockholm & $\begin{array}{l}\text { "How is it possible to create new value chains and business ventures that take the } \\
\text { goals of a city into account and at the same time be profitable for the } \\
\text { participants, given the limited conditions?" }\end{array}$ & Local & $\mathrm{P}$ \\
\hline $\begin{array}{l}\text { van Veenstra \& } \\
\text { van den Broek, } \\
2013\end{array}$ & $\begin{array}{l}\text { IFIP } \\
\text { EGOV }\end{array}$ & $\begin{array}{l}\text { RTO, The } \\
\text { Netherlands }\end{array}$ & $\begin{array}{l}\text { "Which drivers, enablers and barriers exist in organizations that open up their } \\
\text { data to the public"? What are drivers, enablers, and barriers of open data? Do } \\
\text { they remain the same in every phase of the process? }\end{array}$ & National & $\mathrm{P}$ \\
\hline
\end{tabular}


Table 4 gives an overview of the publication outlets of the 26 conference articles and 9 journal articles. Although IS outlets prevail at a conference level, we did not find any published article on this topic in the IS journals that were part of our selection.

Table 4. Publication outlets

\begin{tabular}{|c|c|c|c|}
\hline Journal & Number of articles & Conference & Number of articles \\
\hline GIQ & 4 & HICSS & 9 \\
\hline J Knowl Econ & 2 & IFIP EGOV & 6 \\
\hline TGPPP & 2 & ECIS & 5 \\
\hline Technol Forecast Soc & 1 & Dg.o & 4 \\
\hline & & ECEG & 1 \\
\hline & & ICIS & 1 \\
\hline
\end{tabular}

Although we used 2009 as the starting year for the literature review, case studies on government opening data appear only a couple of years later. For an overview of the number of articles published per year, see Figure 2.

Figure 2. Number of publications per year

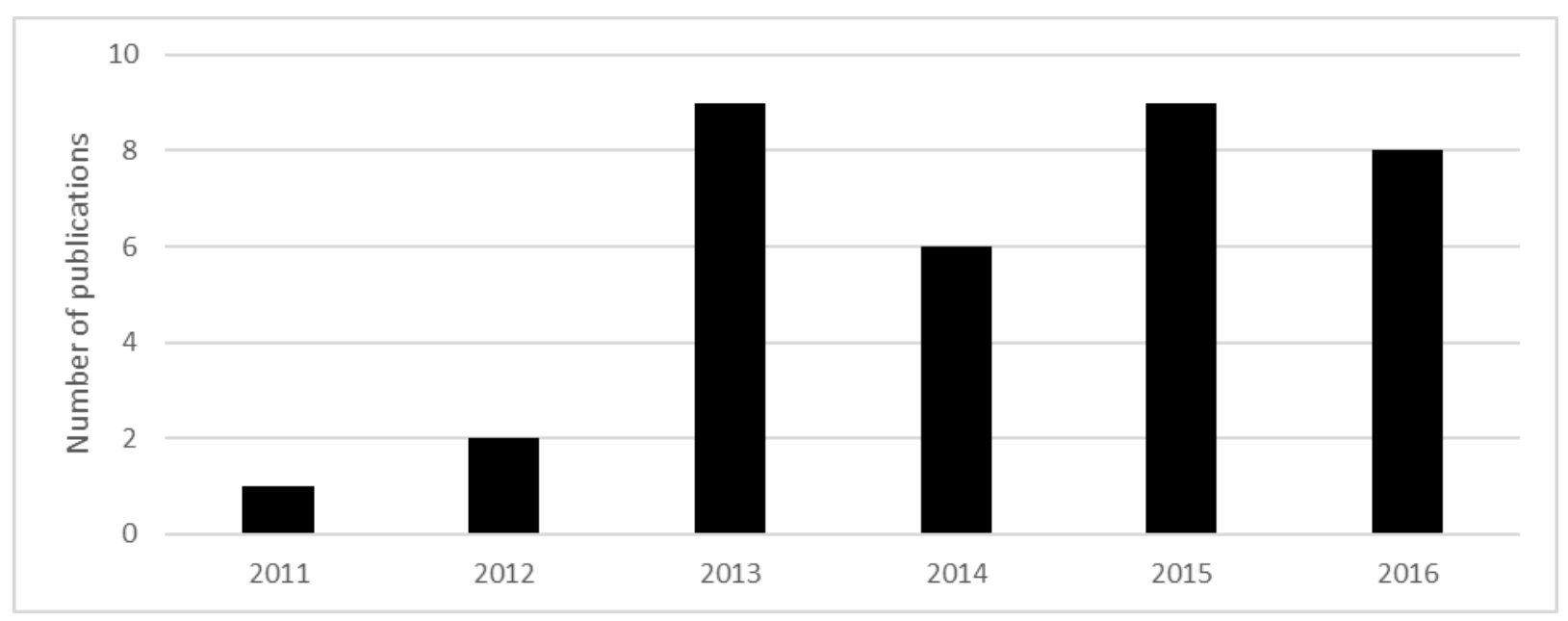




\section{Data analysis and discussion}

In platform research, considerable attention goes to the technological side, whereas the network aspects sometimes remain underexplored. Therefore, we use the network dimensions for OGD platforms (Dawes, Vidiasova \& Parkhimovich, 2016), which fit our definition of an OGD platform, to distinguish between the following aspects: dynamics over time, interactions and interdependencies, feedback and communication among stakeholders, sustainability, government intervention, environmental influences, and enabling actors. Looking for signals of the three OGD platform types in the case studies (not written with this purpose in mind) was not an easy task; it was easier to look for sub-characteristics. In Table 5, we provide an overview of these dimensions, which have been grouped to better reflect the elements of OGD platforms identified in Figure 1.

Table 5. Network dimensions for OGD platforms (based on Dawes et al., 2016)

\begin{tabular}{|l|l|}
\hline Dimension & \multicolumn{2}{l|}{ Question } \\
\hline $\begin{array}{l}\text { Dynamics over time and contextual } \\
\text { responsiveness }\end{array}$ & $\begin{array}{l}\text { How does the environment or context influence the way in } \\
\text { which the OGD platform is organized, and how does the OGD } \\
\text { platform evolve over time? }\end{array}$ \\
\hline Enabling actors & $\begin{array}{l}\text { Which actors are part of the OGD platform, and what are their } \\
\text { interrelationships? }\end{array}$ \\
\hline Interactions and communication & $\begin{array}{l}\text { What do the dialogical processes look like in which discussions } \\
\text { between platform actors occur? }\end{array}$ \\
\hline Government intervention & $\begin{array}{l}\text { What is the content and scope of the role the government plays } \\
\text { with regards to the OGD platform? }\end{array}$ \\
\hline Sustainability & $\begin{array}{l}\text { What are the constraints to the long-term viability of the OGD } \\
\text { platform? }\end{array}$ \\
\hline
\end{tabular}

We clustered the network dimensions because we encountered sparse data: each case study discussed only some of the network dimensions, and there were many missing values. Just like in statistics, we had to define our variables such that each network dimension was covered by a sufficient number of case studies for further analysis and discussion. We grouped two dimensions reflecting characteristics of the open data platform ('dynamics over time' and 
'environmental influences') into one dimension, 'dynamics over time and contextual responsiveness', because in the case study examples, the dynamics over time were always influenced by the environment. Two dimensions focusing on the relationships between the open data platform and the enabling actors ('interactions and interdependencies' and 'feedback and communication among stakeholders') were always covered by the same examples from the case studies and were grouped into the dimension 'interactions and communication'. For each dimension, we propose a question to be answered in the OGD platform context.

In the following subsections, we further elaborate on the OGD platform types in a more detailed discussion for each network dimension. In addition, we systematically looked for elements in the case studies identified in the literature review. For each network dimension, we describe the most interesting examples.

\subsection{Dynamics over time and contextual responsiveness}

This dimension focuses on the dynamics over time of the open data artifact and the way in which the environment influences how the platform is organized.

In the cognitivist view, the open data platform is mostly regarded as a static artifact once it has been produced. The open data artifact consists of datasets that might be further detailed or corrected but stay in the same format. Additional datasets can be added, but the setup of the platform does not change radically over time. The only dynamics described are those of moving from a closed to an open system.

In addition, the open data platform is organized according to a one-size-fits-all approach. It is a neutral tool for storing and disseminating open data. Robinson, Yu, Zeller and Felten (2008) argue that the government's role in processing the data should be minimized or even eliminated 
and that it should focus on "creating a simple, reliable and publicly accessible infrastructure that exposes the underlying data”.

According to the connectionist epistemology, ideally, the open data platform is adapted to the specific context in which it is used. Klievink, Zuiderwijk and Janssen (2014) argue that it is impossible to fully predict the users and types of re-use beforehand and that the open data platform may evolve to take emerging needs into account.

In the autopoietic view, the ecosystem and the open data platform are co-evolving systems: changes in the environment will, by default, elicit the ecosystem to adapt accordingly. All actors, as well as their relationships, contribute to the ecosystem. To become autopoietic, the applications developed with the APIs in Helsinki's Living Lab open data competition (Hielkema \& Hongisto, 2013) could, for example, enrich the open data platform by providing real-time use data of their own application.

Emerging and needs-driven parts of the open data platform are not one-off initiatives but rather result automatically from the platform use. The connectionist view already acknowledged that emerging parts of the open data platform are possible, but they are mostly initiated by the government. For example, a smart city can decide to focus on a specific topic in a Living Lab. In an autopoietic system, however, the open data platform can be enriched by different actors. Enabling many network actors to alter or add to the open data platform will require active governance of what the different actors are allowed to do (Tilson et al., 2010).

\subsection{Enabling actors}

In this dimension, we focus on the enabling actors who together form the network around the open data, and their interrelationships. 
In the cognitivist epistemology, open data are re-used by a single party. Open data users consume open data on an individual basis, and there are no relationships needed with other actors to re-use the data. Janssen, Matheus and Zuiderwijk (2015) recognize that smart cities, for example, are highly dependent on smart citizens, "who are able to make advantage of the knowledge and in this way better utilize resources" to realize the benefits of open data.

In the connectionist epistemology, open data re-use occurs through the connection of several actors. The enabling actors cover different roles along the value chain from open data to re-use, and it is important that all roles are covered. Lindman, Kinnari and Rossi (2014) argue that "for the open data industry to emerge, there need to be more players occupying the roles of 'extract and transform' [data] and open data publisher because these are needed by the user experience providers to create new services".

Intermediate actors may foster connections between the actors re-using the open data. The government can take up this intermediating role, such as in Living Labs or libraries, but the intermediator can also be an external party, such as Code for America (Maruyama, Douglas \& Robertson, 2013).

In the autopoietic view, the actors form a network characterized by ecosystem interdependencies. Lindman et al. (2014) already gave the first hint towards this view by identifying the profiles that are necessary in an open data ecosystem. In the autopoietic view, the steps in the value chain are not one time only, and the artifacts developed along the steps are not restricted to the use of one specific actor. Most importantly, actions enrich the entire ecosystem rather than being limited to a one-way interaction.

Ideally, the ecosystem is organized or governed in such a way that crucial actors will take up their roles for the longer term or new actors will come up and compete with existing ones or fill 
in newly created spots (Wareham et al., 2014). It is not enough that all necessary roles are taken up at a static point in time. Rather, the autopoietic open data ecosystem is an autonomous system that recreates itself.

\subsection{Interactions and communication}

This dimension focuses on the interactions and communication between platform actors.

In the cognitivist epistemology, the focus is limited to the relationship between the re-user of the data and the data themselves. The goal is to organize the open data platform for querying by individual open data users. This means that interactions and interdependencies are limited to a one-sided data supplying relationship, corresponding to what Pollock (2011) labelled "open data as a one-way street". If necessary, a connection between the data and potential users is actively fostered (Hjalmarsson, Johannesson, Juell-Skielse \& Rudmark, 2015).

The connectionist epistemology focuses on two-way interactions between parties connecting offline to re-use the data. Often, the connections are facilitated by the government during hackathons (see, e.g., Hellberg \& Hedström, 2015; Hielkema \& Hongisto, 2013; Hjalmarsson et al., 2014; Hjalmarsson, Johansson \& Rudmark, 2015; Juell-Skielse, Hjalmarsson, Johannesson \& Rudmark, 2014).

Ultimately, interactions and communication between the government and society are transformed by open data. The one-way push from the government to its citizens is reimagined as a co-creative relationship in which society can build on the government's data (Bertot, Butler \& Travis, 2014; Kassen, 2013).

In the autopoietic view, feedback from actors re-using the data and from their interactions forms the basis for a learning platform, where re-use of the OGD further enriches the platform. This 
contrasts with the cognitivist epistemology, in which there are no feedback loops from the re-use to the platform or to other actors and interactions are mostly data driven rather than needs driven (Janssen et al., 2015; Susha, Grönlund \& Janssen, 2015). It also differs from the connectionist epistemology, in which feedback loops are limited to local connections between actors and feedback loops between the actors and the platform are lacking. This means that communication does not reach all complementors in the ecosystem but is limited to local connections. Kuk and Davies (2011) described how open data hackers started sharing tools with parties with whom they collaborated, but in an autopoietic system, such functionalities could become part of the open data platform.

\subsection{Government interventions}

This dimension focuses on the content and the scope of the role the government plays with regards to the open data platform.

In the cognitivist view, the government opens its data to be re-used but does not intervene much beyond setting up an open data platform. This can be a conscious choice, depending on the context, as government interventions are not always possible or even desirable.

Providing an open data platform might indeed be enough to foster re-use in some cases, where the demand for open data is externally driven from the beginning (see, e.g., Rudmark, Arnestrand \& Avital, 2012). In other cases, some marketing may be necessary to connect open data users to the open data platform. Still, realizing that the government does not have to develop all services by itself is an important step in moving from a service provision strategy to a platform strategy. 
In the connectionist view, the government acts as a central coordination mechanism and creates communities around open data. This includes attracting and connecting parties re-using open data. The need for a central coordinating mechanism is also recognized by Bertot et al. (2014), who find that none of the actors have the capacity to "do it all".

In the autopoietic view, the government acts as the keystone orchestrating the ecosystem. Rather than actively coordinating the actors in the open data network, a keystone designs mechanisms that ensure that the ecosystem organizes itself. The role of the keystone consists of two parts: creating value and fostering the health of the ecosystem (Iansiti \& Levien, 2004). With the open data platform, the government can offer essential services, tools, or technologies that provide solutions to others in the ecosystem. The government as a keystone also needs to foster the health of the ecosystem by making sure that ecosystem parties want to join and remain around the table.

In an autopoietic open data ecosystem, self-regulation is steered by governance rules balancing control and variety in open data re-use (Wareham et al., 2014). For example, if the open data ecosystem focuses more on certain areas, such as mobility, the government could apply governance rules to steer attention towards other important, but less popular, areas as well. In a keystone role, the government will have to balance the freedom of letting all parties do what they want with keeping some control over what is produced.

\subsection{Sustainability}

This dimension focuses on the constraints to the long-term viability of the open data platform.

In the cognitivist epistemology, the focus is on the data per se. Ideally, the range and reach of the data sources are increased regularly, and updates and problem solving occur in response to 
comments or complaints. This resonates with the finding of Attard et al. (2015) that most challenges found in the literature are of a technical nature, i.e., related to the format, ambiguity, discoverability, and representation of the data.

In the connectionist view, sustainability implies that actors remain committed once they have joined the platform. Hence, the focus is broadened to also include sustainable actor engagement, and sustainable connections between the actors. In this respect, Kuk and Davies (2011) warn that efforts of connecting actors are concentrated too much on the early design phases; these early prototypes can be sustained only when the focus of stimulating collaboration is broadened to also include later design phases.

Ideally, sustained participation of platform actors leads to more products or services resulting from the open data re-use, i.e., higher productivity (Iansiti \& Levien, 2004). However, Hjalmarsson et al. (2015b) argue that innovation contests, in their current set-up, have trouble reaching high productivity levels.

In the autopoietic view, the aim is to guarantee the sustainability of the entire ecosystem. If the government aims to become the keystone of a thriving open data ecosystem, it will have to cater to the ecosystem's health. This implies a focus on productivity, robustness, and niche creation (Iansiti \& Levien, 2004). The connectionist view already focused on increasing the productivity of the ecosystem by simplifying the complex task of connecting ecosystem parties to one another and by making the creation of new products by these parties more efficient. In an autopoietic system, there is also a focus on guaranteeing robustness by consistently incorporating technological innovations and by providing a reliable point of reference that helps participants respond to new and uncertain conditions. In addition, OGD platforms have the aim of creating 
meaningful diversity, which is stimulated by offering innovative technologies to a variety of third parties.

Ecosystem sustainability also includes balancing paradoxes in the ecosystem's outputs, actors, and identifications (Wareham et al., 2014). For each of the three paradoxes, the keystone has to create appropriate governance mechanisms that balance the increase of desirable variance and the decrease of undesirable variance. In the outputs, mostly apps or other results of OGD re-use, standardization has to be balanced relative to the creation of specialized complements and constant experimentation. Towards the actors re-using OGD, control on the quality of the process, product, and excess supply has to be balanced with mechanisms leveraging the autonomy for innovation. In the identifications of the ecosystem actors, each individual actor should be able to work towards its own benefit, but this has to be balanced with a focus on the collective benefits for the ecosystem.

\subsection{Elements in the case studies}

In Table 6, we describe some of the most interesting elements from the case studies identified in the literature review, for each combination of the knowledge epistemologies and the network dimensions. 
Table 6. Elements in the case studies

\begin{tabular}{|c|c|c|c|}
\hline & Cognitivist elements & Connectionist elements & Autopoietic elements \\
\hline $\begin{array}{l}\text { Dynamics over } \\
\text { time and } \\
\text { contextual } \\
\text { responsiveness }\end{array}$ & $\begin{array}{l}\text { Rudmark et al. (2012) } \\
\text { describe how the Swedish } \\
\text { public transport company } \\
\text { has moved from closed to } \\
\text { open, and more specifically } \\
\text { how it was pushed to become } \\
\text { more open. } \\
\text { Statistical agencies in Sweden } \\
\text { and The Netherlands } \\
\text { abstracted from the context } \\
\text { in which their open data } \\
\text { platform would be used } \\
\text { because of the complexity of } \\
\text { the environment consisting } \\
\text { of different types of users } \\
\text { (Susha et al., 2015). }\end{array}$ & $\begin{array}{l}\text { Public transport authorities, together with a city-run } \\
\text { Living Lab, initiated the HsL open data competition, } \\
\text { focused on re-using transportation datasets from the } \\
\text { Helsinki area (Hielkema \& Hongisto, 2013) } \\
\text { Information infrastructures evolve with their context: "as } \\
\text { the II [Information Infrastructure] and its services } \\
\text { change, the type of users and usage also changes" } \\
\text { (Klievink et al., 2014). } \\
\text { Trafiklab, an open data marketplace distributing open } \\
\text { public transport data in Sweden, intends to act as "a } \\
\text { community for open data users, as an initiative to } \\
\text { catalyze the further provision of open data from the } \\
\text { public transport sector as well as a support function for } \\
\text { transport authorities that want to disclose data on their } \\
\text { own terms." (Smith et al., 2016) }\end{array}$ & $\begin{array}{l}\text { - On the Chicago open data portal, it } \\
\text { is possible to hold online } \\
\text { discussions, and fill out an } \\
\text { interactive feedback form (Kassen, } \\
\text { 2013) } \\
\text { "The II is open in the sense that any } \\
\text { organization, business or person } \\
\text { can use the II and contribute to it by } \\
\text { adding datasets and applications } \\
\text { that are not available in the II yet or } \\
\text { by connecting extended (e.g., } \\
\text { cleansed) datasets and the results of } \\
\text { data use to the original dataset." } \\
\text { "Technical components and systems } \\
\text { (e.g., forums, Wiki's and data } \\
\text { quality rating systems) enable social } \\
\text { interaction between users." } \\
\text { (Klievink et al., 2014) }\end{array}$ \\
\hline $\begin{array}{l}\text { Enabling } \\
\text { actors }\end{array}$ & $\begin{array}{l}\text { Maccani et al. (2015) give the } \\
\text { example of a company that } \\
\text { visualizes planning and } \\
\text { building permit data from } \\
\text { open datasets. }\end{array}$ & $\begin{array}{l}\text { - Hielkema and Hongisto (2013) see Living Labs as } \\
\text { intermediaries connecting the providers of open data } \\
\text { with the developer community. They show "how Living } \\
\text { Labs in their role of innovation intermediary can } \\
\text { facilitate the collaboration between various actors in the } \\
\text { mobile application cluster. By bringing challenges to the } \\
\text { developer community [and supporting the resulting } \\
\text { applications in the media], they drive the use of open } \\
\text { data and further the smart city development." } \\
\text { Bertot et al. (2014) present the case of local libraries } \\
\text { bringing stakeholder communities together and } \\
\text { developing a range of skills, acting as central } \\
\text { coordinating mechanisms or community platforms. } \\
\text { As part of the Danish Basic Data Program (BDP), a data } \\
\text { ambassador was hired relatively early in the program. } \\
\text { "His responsibility was to serve as a communication } \\
\text { channel between the BDP and potential private sector } \\
\text { users, ensuring that relevant information was shared bi- } \\
\text { directionally." (Jetzek, 2016) }\end{array}$ & No examples \\
\hline $\begin{array}{l}\text { Interactions } \\
\text { and inter- } \\
\text { dependencies }\end{array}$ & $\begin{array}{l}\text { - An interviewee of the city of } \\
\text { Seattle stated that open data } \\
\text { are especially useful in } \\
\text { informing the public about }\end{array}$ & $\begin{array}{l}\text { Hellberg and Hedström (2015) indicate that many } \\
\text { hackathon participants join with the aim to connect to } \\
\text { others: "approximately a fifth was contestants; the other } \\
\text { participants were there for networking purposes. For }\end{array}$ & $\begin{array}{l}\text { The Dutch CBS uses a specialized } \\
\text { member-only LinkedIn group, } \\
\text { which served a combination of } \\
\text { functions: to post news and share }\end{array}$ \\
\hline
\end{tabular}




\begin{tabular}{|c|c|c|c|}
\hline & $\begin{array}{l}\text { what the city is doing: "I } \\
\text { don't think it's so much } \\
\text { utilize information to help } \\
\text { each other as it is to help our } \\
\text { constituents out there, to let } \\
\text { the public know better what } \\
\text { we're doing and how we're } \\
\text { doing it and how we might be } \\
\text { impacting their street or their } \\
\text { electricity." (Al Awadhi \& } \\
\text { Scholl, 2013) }\end{array}$ & $\begin{array}{l}\text { instance, the organizers of the music festivals aim was to } \\
\text { get hold of someone who could work with their webpage, } \\
\text { a task they succeeded with." } \\
\text { Maruyama et al. (2013) discussed how Code for America } \\
\text { fellows were instrumental in connecting different actors, } \\
\text { both inside and outside government: "Sometimes the } \\
\text { fellows acted as a hub for a network of existing change } \\
\text { agents - rather than as initiators of change themselves. } \\
\text { The fellows were connected with an alliance of } \\
\text { supporters within the city, which included city } \\
\text { employees, technologists, politicians and citizens. The } \\
\text { fellows added value to the alliance by introducing } \\
\text { enthusiastic supporters within the city to each other and } \\
\text { connecting local change makers to their counterparts } \\
\text { elsewhere in the U.S." (Maruyama et al., 2013) } \\
\text { Trafiklab in Sweden regularly organizes meet-ups aimed } \\
\text { at "stimulating interaction between stakeholders and to } \\
\text { increase their involvement and insight in the } \\
\text { development of the marketplace. At these meet-ups, data } \\
\text { users interact face-to-face with other data users, } \\
\text { exchange ideas on applications and share their } \\
\text { motivation behind those applications. Furthermore, } \\
\text { arranging meet-ups is also a means of gathering users' } \\
\text { input and attracting new members to the community." } \\
\text { (Smith et al., 2016) }\end{array}$ & $\begin{array}{l}\text { materials, support discussions, } \\
\text { answer questions, invite feedback } \\
\text { on API performance, submit error } \\
\text { reports, offer mentoring, etc.(Susha } \\
\text { et al., 2015) }\end{array}$ \\
\hline $\begin{array}{l}\text { Government } \\
\text { interventions }\end{array}$ & $\begin{array}{l}\text { - } \\
\text { describe how the insight that } \\
\text { government should no longer } \\
\text { provide all services by itself } \\
\text { pushed the Swedish Public } \\
\text { Transport Company to open } \\
\text { up its data: “[The most } \\
\text { popular iPhone application] } \\
\text { is a prime example of that it } \\
\text { is not necessarily we at SPTC } \\
\text { who best can produce useful } \\
\text { digital services for travelers. } \\
\text { We hope that this initiative } \\
\text { will lead to many more smart } \\
\text { services to accommodate } \\
\text { different types of travelers, } \\
\text { says [Head of Internet } \\
\text { Services, SPTC]" (Rudmark } \\
\text { et al., 2012). }\end{array}$ & $\begin{array}{l}\text { - In Helsinki "the role of government is visible in several of } \\
\text { the actors and key incentives: in the provision of the } \\
\text { open data and APIs, in the role as purchaser of services, } \\
\text { as a supporting partner, and as owner of the Living Lab } \\
\text { collaborative network and facilitation". (Hielkema \& } \\
\text { Hongisto, 2013) } \\
\text { The role of government also includes attracting and } \\
\text { connecting actors re-using open data by "social media, } \\
\text { workshops, websites, blogs, video, hackathons, education } \\
\text { and tutorials, newsletters, networks of project partners, } \\
\text { presentations and brochures" (Klievink et al., 2014). } \\
\text { The eGovernment Master Plan in Singapore recognizes } \\
\text { that "the role of the public sector becomes one of a } \\
\text { facilitator that harnesses the strength of various parts of } \\
\text { the society to meeting the needs of the individual } \\
\text { citizens. The new eGovernment Master Plan is all about } \\
\text { the government adopting an enabling and facilitating } \\
\text { role enabled by technology to deliver public value. It's } \\
\text { about viewing data as a strategic infrastructure and using } \\
\text { it effectively... [The portal provides] opportunities for the }\end{array}$ & $\begin{array}{l}\text { - In Singapore, innovation } \\
\text { competitions and call-for- } \\
\text { collaborations are used for different } \\
\text { purposes in a way to balance push } \\
\text { and pull. Innovation competitions } \\
\text { "appeared to be conducive for } \\
\text { creating awareness and enticing } \\
\text { broad participation but were weak } \\
\text { in assuring the creation of specific } \\
\text { high quality e-services", while a } \\
\text { Call-For-Collaboration invited } \\
\text { "companies to submit proposals to } \\
\text { develop and deploy specific e- } \\
\text { services" (Chan, 2013). }\end{array}$ \\
\hline
\end{tabular}




\begin{tabular}{|c|c|c|c|}
\hline & & $\begin{array}{l}\text { Government to collaborate with the people and private } \\
\text { sector to co-create new e-services and approaches to } \\
\text { service delivery." (Chan, 2013) }\end{array}$ & \\
\hline Sustainability & $\begin{array}{l}\text { Hjalmarsson et al. (2015a) } \\
\text { argue that systematic open } \\
\text { data assessment may help } \\
\text { open data providers } \\
\text { understand where the gaps } \\
\text { are and what can be } \\
\text { improved. The assessment } \\
\text { starts with an overall } \\
\text { assessment of the open data } \\
\text { resources available. Each of } \\
\text { the data sources is then } \\
\text { analyzed using six generic } \\
\text { dimensions: access, support, } \\
\text { license terms, costs, technical } \\
\text { format, and quality. } \\
\text { Identifying the differences } \\
\text { between the data sources on } \\
\text { each of these dimensions can } \\
\text { identify opportunities for } \\
\text { improvement. }\end{array}$ & $\begin{array}{l}\text { The data-use instances demonstrated the innovation } \\
\text { possibilities, but rarely were they sustained or developed } \\
\text { into sustainable services. [...] The active projects } \\
\text { exhibited several unique characteristics [...]. They } \\
\text { comprised: not a loner project; having immediate } \\
\text { relevance and appeal to the hackers; devising a technical } \\
\text { solution to a well-defined problem; aiming to form an } \\
\text { open source community; seeking to improve the reuse } \\
\text { value of data and other associated artifacts; and seeking } \\
\text { to exploit the resulting technologies for service } \\
\text { innovation and/or profit. Whereas other non-active } \\
\text { projects were characterized by short-term goals, i.e., } \\
\text { using open data to solve a problem of personal needs and } \\
\text { use benefit (use value (Kuk \& Davies, 2014). } \\
\text { At Monithon.it, an initiative performing civic monitoring } \\
\text { activities on open data, "a major challenge for } \\
\text { sustainability is creating enduring local groups with } \\
\text { sufficient motivation and specific, interdisciplinary } \\
\text { expertise to do this kind of work." (Reggi \& Dawes, 2016) }\end{array}$ & No examples \\
\hline
\end{tabular}




\subsection{Summary of the OGD platform classification}

The characterization of the three knowledge epistemologies according to the network dimensions

resulted in Table 7. The case study elements from the literature review serve as a validation of

the table and an illustration thereof.

Table 7. Knowledge epistemologies for OGD ecosystems (based on Dawes et al., 2016; Skok \&

Kalmanovitch, 2005; von Krogh \& Roos, 1998)

\begin{tabular}{|c|c|c|c|}
\hline Dimension & Cognitivist & Connectionist & Autopoietic \\
\hline $\begin{array}{l}\text { Dynamics over time and } \\
\text { contextual responsiveness }\end{array}$ & $\begin{array}{l}\text { The OGD platform is mostly } \\
\text { regarded as a static artifact, as } \\
\text { a neutral tool for storing and } \\
\text { disseminating open data, } \\
\text { organized according to a one- } \\
\text { size-fits-all approach. }\end{array}$ & $\begin{array}{l}\text { The OGD platform ideally } \\
\text { evolves to take the context of } \\
\text { open data re-use into account, } \\
\text { and emerging and more } \\
\text { needs-driven parts are } \\
\text { possible. }\end{array}$ & $\begin{array}{l}\text { Dynamic co-evolution with } \\
\text { context occurs automatically: } \\
\text { changes in the environment } \\
\text { will by default elicit the OGD } \\
\text { platform to adapt } \\
\text { accordingly. Emerging and } \\
\text { needs-driven parts of the } \\
\text { platform are not one-off } \\
\text { initiatives, but result } \\
\text { automatically from platform } \\
\text { use. }\end{array}$ \\
\hline Enabling actors & $\begin{array}{l}\text { Actors re-using open data } \\
\text { have no need for relationships } \\
\text { with other actors to re-use the } \\
\text { data. }\end{array}$ & $\begin{array}{l}\text { Open data re-use occurs } \\
\text { through the connection of } \\
\text { several actors, covering } \\
\text { different roles along the value } \\
\text { chain from open data to re- } \\
\text { use. Intermediate actors can } \\
\text { play an important role in } \\
\text { connecting others. }\end{array}$ & $\begin{array}{l}\text { OGD platform actors form a } \\
\text { self-organizing network or } \\
\text { ecosystem characterized by } \\
\text { complex ecosystem } \\
\text { interdependencies. Actors } \\
\text { take up their roles for the } \\
\text { longer term, or new actors } \\
\text { come up and compete with } \\
\text { existing ones. }\end{array}$ \\
\hline $\begin{array}{l}\text { Interactions and } \\
\text { communications }\end{array}$ & $\begin{array}{l}\text { Controlled by the } \\
\text { government: one-way supply } \\
\text { of OGD to open data users, } \\
\text { and one-way communication } \\
\text { push. }\end{array}$ & $\begin{array}{l}\text { Two-way interactions } \\
\text { between actors whose } \\
\text { connection is enabled by } \\
\text { OGD, often facilitated by } \\
\text { government. }\end{array}$ & $\begin{array}{l}\text { Feedback from actors re- } \\
\text { using the data and from their } \\
\text { interactions forms the basis } \\
\text { for a learning platform. }\end{array}$ \\
\hline Government intervention & $\begin{array}{l}\text { Government realizes that it } \\
\text { does not have to develop all } \\
\text { services by itself and opens } \\
\text { its data to be re-used and } \\
\text { connects users to the open } \\
\text { data. }\end{array}$ & $\begin{array}{l}\text { Government acts as a central } \\
\text { coordination mechanism for } \\
\text { creating communities around } \\
\text { open data. }\end{array}$ & $\begin{array}{l}\text { Government acts as the } \\
\text { keystone orchestrating the } \\
\text { open data ecosystem by } \\
\text { creating value and fostering } \\
\text { the health of the ecosystem. }\end{array}$ \\
\hline Sustainability & Focus on the data per se. & $\begin{array}{l}\text { Focus on sustained } \\
\text { commitment of the platform } \\
\text { actors and their connections. }\end{array}$ & $\begin{array}{l}\text { Focus on making the entire } \\
\text { ecosystem thrive. }\end{array}$ \\
\hline
\end{tabular}


As we present the platform types as an evolution, with each type adding some elements compared to the scope of the previous type, not all individual elements or cells in Table 7 have to be distinctive when comparing platform types. Rather, all elements as a whole define each platform type as distinctive from the other types.

\section{Synthesis and research agenda}

Contrary to the popularity of OGD and high hopes expressed by O'Reilly (2011), a recently published article in The Economist (Out of the box, 2015) asks whether the open data movement will really effect a transformation and claims it is reasonable to ask why more has not been achieved. The research on barriers to OGD (Huijboom \& Van den Broek, 2011; Van Veenstra \& Van den Broek, 2013; Zuiderwijk et al., 2012a, 2012b) gave rise to a more realistic perspective on OGD, and several authors have argued for the need to take complex interactions with multiple actors into account (Brown et al., 2014; Harrison et al., 2012; Janssen \& Estevez, 2013).

We argue that, given the importance of collaborating with multiple stakeholders, more research on network aspects of OGD platforms will be required. Through the literature review, we brought to light differences in focus in the case study research for the three OGD platform types. In the literature review, we looked for elements of three platform types in the case study research on OGD platforms. In general, we found only a limited number of studies adopting a network approach, focusing on the management and governance of a combination of the technical side

and the actors in the innovation network. Moreover, we found a strong focus on cognitivist and especially connectionist platform elements, and a lack of research on autopoietic elements.

Each network dimension, regardless of the OGD platform type, was covered by only a limited number of case studies. This is especially true for the dimensions 'government intervention' and 
'sustainability'. The number of case studies covering several network dimensions is even lower. However, to make sense of the complexity and interdependency of a diverse set of actors and OGD platforms, the network perspective is ideally suited. This highlights a need for further research taking a network perspective to OGD platforms.

Despite this general lack of the network perspective, we covered several cognitivist and connectionist examples for each network dimension individually. Although we found a small amount of elements hinting towards the autopoietic platform type, we did not find any fully realized elements in the case study literature. It is not clear why this is the case. Are there no practical examples of autopoietic OGD platforms, or has the autopoietic view not been adopted by research? We are convinced that the autopoietic view deservers further attention. Moreover, if the open data community wants to understand why more has not been achieved and what could be done to achieve more, the autopoietic view on OGD platforms deserves a much more central position in the field.

We propose two types of questions for further research. First, further research could focus on why the autopoietic view remains absent in the case study literature. Is it a conscious choice that the autopoietic view is not applied? Are there barriers to applying the autopoietic view, and if so, are these of a practical, political or other nature? Second, despite the remarks that autopoietic OGD platforms will not always be possible or desirable, it is striking that we did not find any clearly elaborated example in the literature. To encourage research on the autopoietic view, we developed a research agenda focusing specifically on important questions associated with the autopoietic OGD platform type. 
Table 8. Research agenda for OGD platforms (based on Hagiu, 2014)

\begin{tabular}{|c|c|}
\hline Strategic questions for MSPs & Research agenda for OGD platforms \\
\hline How many parties? & $\begin{array}{l}\text { Empirical examples of how many parties to actively involve in the OGD platform } \\
\text { and trade-offs between parties: } \\
\text { - } \quad \text { Is there an optimal number of parties to involve? } \\
\text { - Which parties are indispensable? } \\
\text { - Which parties cannot co-exist in a sustainable OGD platform? } \\
\text { - In which cases does a trade-off have to be made between which parties to } \\
\text { - } \quad \text { Involve? } \\
\text { Empovernment always the central party or platform orchestrator? } \\
\text { OGD platform: } \\
\text { - } \quad \text { Does this help for growing the ecosystem? } \\
\text { - Which roles can best be covered by government? } \\
\text { - And how does government eventually transfer this role to another party? }\end{array}$ \\
\hline Which features and functionalities? & $\begin{array}{l}\text { If OGD platforms aim to go beyond the data catalogues they tend to be now, } \\
\text { which features and functionalities are crucial? } \\
\text { Are there features that put the interest of different ecosystem parties at odds with } \\
\text { each other? } \\
\text { How should this conflict of interest be resolved? }\end{array}$ \\
\hline Pricing? & $\begin{array}{l}\text { Is losing income an important barrier to freeing up some of the most valuable } \\
\text { data? } \\
\text { What are viable business models for open data re-use? }\end{array}$ \\
\hline Governance decisions? & $\begin{array}{l}\text { Who is allowed to join the ecosystem, and which parts of the OGD platform can } \\
\text { they access? } \\
\text { What are the various parties allowed to do, and with whom are they allowed to } \\
\text { interact on the platform? } \\
\text { Do governance rules have to be created by a central party? } \\
\text { How is the trade-off between quantity and quality of open data re-use handled? In } \\
\text { which cases is one strategy preferred over the other? } \\
\text { How does government ensure that low-quality suppliers do not drive out high- } \\
\text { quality suppliers? } \\
\text { How will it be ensured that parties take actions that not only are positive for } \\
\text { themselves but also have positive spillover effects? }\end{array}$ \\
\hline
\end{tabular}

An autopoietic view is associated with key questions regarding ecosystem platform management and governance. To develop a research agenda, we therefore look at the most important questions to be answered in the platform literature. Hagiu (2014) argued that thinking of open 
data as the basis of a platform business model requires taking four important decisions into account. To fully support or foster knowledge-based interaction, the OGD literature should focus on these four decisions: How many different parties can be part of the ecosystem? Which features and functionalities should be part of the platform? What should pricing look like? Which governance decisions should we make?

In Table 8, we list a research agenda for autopoietic OGD platforms for each of the four strategic questions. This research agenda serves as a first attempt for research on the network dimensions in an autopoietic view.

\section{Conclusion}

This article was developed out of alternative expectations of OGD, which might be caused by different definitions of what an OGD platform is. We proposed different types of OGD platforms by reinterpreting the lens of knowledge epistemologies. We performed a literature review and looked for elements of each type of OGD platform in open data case studies in the main egovernment outlets (Scholl \& Dwivedi, 2014) to validate and further enrich the OGD platform types.

The first contribution to the literature and to practice is the proposition of three types of OGD platforms: a cognitivist interaction between users and the data, connectionist interactions between different actors re-using open data collaboratively, and an autopoietic system in which each actor enriches the ecosystem through the platform's use. A second contribution is that we explore, through empirical examples from the literature review, how the platform types led to different foci for research on OGD platforms, for different network dimensions. The platform types contribute to the OGD literature by offering a better framing for certain debates. Relating 
to the OGD ecosystem literature, enthusiasm around the advantages of the autopoietic platform type has not yet been complemented with ample research on the implications of this approach, and more research taking ecosystem or network aspects into account is necessary. The distinction between the platform types could also contribute to the literature focusing on barriers to OGD, as future research could focus on distinguishing between barriers linked with the different platform types.

Looking for elements of the 3 OGD platform types in 35 articles resulted in pressing questions for future research. We found only a limited number of studies adopting a network approach. Therefore, this article calls for more focus on systematic data collection on the key governance decisions to be made for OGD platforms from a network perspective. We covered examples studying cognitivist and connectionist elements, but there was a lack of research focusing on autopoietic elements. As a first answer to the underrepresentation of the autopoietic view, further research could focus on barriers associated with applying the autopoietic view, both in practice and in research. In addition, we would like to encourage research aiming to overcome this barrier, by focusing on the most important decisions to be made in an autopoietic OGD platform. This will require rich and contextualized longitudinal case studies on how the interactions enrich not only the data but the entire ecosystem.

There are several limitations linked to this exploratory study. First, we reused the case studies for interpretation according to the knowledge epistemologies lens, and this is beyond their initial purpose. As the case studies have not been written with the aim of being mapped on the OGD platform typology, certain elements relevant for the mapping exercise might have been omitted from the case description because of the original focus of the paper. Therefore, it is difficult to distinguish the reasons we did not find any fully realized examples of the autopoietic platform 
type: Is it because the authors did not focus on autopoietic elements of the cases, or did the cases not show any autopoietic elements? To ensure the validity of the mapping, future research could validate with the authors whether the case study elements were classified correctly. Second, we looked at the cases through the lens of the author and thus mapped the articles rather than the cases themselves. This not only implies a time-sensitive snapshot of the case but also introduces a time lag between what is currently occurring and what has been published about cases in the past. Third, choosing the network dimensions lens (Dawes et al., 2016) - which is closely linked to the autopoietic platform type - to analyze the elements from all three OGD platform types might have influenced the results of the analysis and the subsequent discussion section. Fourth, we presented the government as the central party orchestrating the OGD platform. Future research could focus on whether this always is (or has to be) the case, or whether the central party has to create all governance rules.

We hope, however, that our plea for a network approach to OGD platforms and for starting to apply an autopoietic view - as a complement to the cognitivist and connectionist view - will stimulate practitioners to revisit aspirations accordingly and will encourage researchers to focus on important questions associated with all three OGD platform types.

\section{Acknowledgements}

This research was supported by the VDAB research chair on digital business innovation of public services at KU Leuven. 


\section{References}

AlAwadhi, S. \& Scholl, H. J. (2013). Aspirations and realizations: The smart city of Seattle. In HICSS 2013: Proceedings of the $46^{\text {th }}$ Annual Hawaii International Conference on System Sciences. Maui, Hawaii, USA.

Attard, J., Orlandi, F., Scerri, S. \& Auer, S. (2015) A systematic review of open government data initiatives, Government Information Quarterly, 32(4), 399-418.

Bakici, T., Almirall, E., \& Wareham, J. (2013). A smart city initiative: The case of Barcelona. Journal of the Knowledge Economy, 4(2), 135-148.

Berners-Lee, T. (2010). Linked Data. URL: http://www.w3.org/DesignIssues/LinkedData.html (visited on 30 June 2017)

Bertot, J. C., Butler, B. S., \& Travis, D. M. (2014). Local big data: the role of libraries in building community data infrastructures. In dg.o 2014: Proceedings of the 15th Annual International Conference on Digital Government Research. Aguascalientes, Mexico.

Brown, A., Fishenden, J., \& Thompson, M. (2014) Digitizing Government. Palgrave Macmillan.

Bruner, J.S., \& Anglin, J.M. (1973). Beyond the information given. Norton \& Co., New York.

Chan, C. M. (2013). From open data to open innovation strategies: Creating E-services using open government data. In HICSS 2013: Proceedings of the $46^{\text {th }}$ Annual Hawaii International Conference on System Sciences. Maui, Hawaii, USA.

Danneels, L., \& Viaene, S. (2015). Simple rules strategy to transform government: An ADR approach. Government Information Quarterly, 32(4), 516-525.

Dawes, S. S., Vidiasova, L., \& Parkhimovich, O. (2016). Planning and designing open government data programs: An ecosystem approach. Government Information Quarterly, 33(1), 15-27.

Effing, R., \& Groot, B.P. (2016). Social smart city: Introducing digital and social strategies for participatory governance in smart cities. Electronic Government, Springer International Publishing, 241-252.

Elbadawi, I. A. (2012). The State of Open Government Data in GCC Countries. In ECEG 2012: Proceedings of the 12th European Conference on eGovernment. Barcelona, Spain. 
Fitzgerald, M. (2016). Data-driven city management: A close look at Amsterdam's smart city initiative. MIT Sloan Management Review, May 2016.

Gawer, A. (2014). Bridging differing perspectives on technological platforms: Toward an integrative framework. Research Policy, 43(7), 1239-1249.

Ghazawneh, A., \& Henfridsson, O. (2011). Micro-strategizing in platform ecosystems: a multiple case study. In ICIS 2011: Proceedings of the 2011 International Conference on Information Systems, Shanghai, China.

Gonzalez-Zapata, G., \& Heeks, R. (2015). The multiple meanings of open government data: Understanding different stakeholders and their perspectives. Government Information Quarterly, 32(4), 441-452.

Hagiu, A. (2014). Strategic decisions for multisided platforms. MIT Sloan Management Review, 55(2), 7180.

Harrison, T. M., Pardo, T. A., \& Cook, M. (2012). Creating open government ecosystems: A research and development agenda. Future Internet, 4(4), 900-928.

Hellberg, A. S., \& Hedström, K. (2015). The story of the sixth myth of open data and open government. Transforming Government: People, Process and Policy, 9(1), 35-51.

Henderson, J.C., Kulatilaka, N., Venkatraman, N. \& Freedman, J. (2003). Riding the waves of emerging technologies: Opportunities and challenges for the CIO. URL: http://people.bu.edu/jfreedma/Riding\%2othe\%20wave.pdf (visited on 14/12/2016).

Hielkema, H., \& Hongisto, P. (2013). Developing the Helsinki smart city: the role of competitions for open data applications. Journal of the Knowledge Economy, 4(2), 190-204.

Hjalmarsson, A., Johannesson, P., Juell-Skielse, G., \& Rudmark, D. (2014). Beyond innovation contests: A framework of barriers to open innovation of digital services. In ECIS 2014: Proceedings of the Twenty Third European Conference on Information Systems, Münster, Germany.

Hjalmarsson, A., Johansson, N., \& Rudmark, D. (2015). Mind the Gap: Exploring Stakeholders' Value with Open Data Assessment. In HICSS 2015: Proceedings of the $48^{\text {th }}$ Annual Hawaii International Conference on System Sciences. Kauai, Hawaii, USA. 
Howard, R., Blanton, C.E., Holgate, R., Cannon, N., \& Tratz-Ryan, B. (2016). The top 10 strategic technology trends for government in 2016. Gartner. (ID: Go0308910). Retrieved from Gartner database.

Hu, Y., Bai, X., \& Sun, S. (2016). Readiness assessment of open government data programs : A case of Shenzen. In dg.o 2016: Proceedings of the 17th Annual International Conference on Digital Government Research. Shanghai, China.

Huijboom, N., \& Van den Broek, T. (2011). Open data: An international comparison of strategies. European Journal of ePractice, 12(1), 4-16.

Huntgeburth, J. C., \& Veit, D. J. (2013). A Research Agenda for Evaluating Open Government Initiatives. In ECIS 2013: Proceedings of the Twenty First European Conference on Information Systems, Utrecht, The Netherlands.

Iansiti, M. \& Levien, R. (2004). Strategy as ecology. Harvard Business Review, 82(3), 68-81.

Janssen, M., \& Estevez, E. (2013). Lean government and platform-based governance - Doing more with less. Government Information Quarterly, 30, S1-S8.

Janssen, M., Matheus, R., \& Zuiderwijk, A. (2015). Big and Open Linked Data (BOLD) to Create Smart Cities and Citizens: Insights from Smart Energy and Mobility Cases. Electronic Government. Springer International Publishing, 79-90.

Jetzek, T. (2016). Managing complexity across multiple dimensions of liquid open data: The case of the Danish Basic Data Program. Government Information Quarterly, 33(1), 89-104.

Juell-Skielse, G., Hjalmarsson, A., Johannesson, P., \& Rudmark, D. (2014). Is the Public Motivated to Engage in Open Data Innovation? Electronic Government. Springer Berlin Heidelberg, 277-288.

Kassen, M. (2013). A promising phenomenon of open data: A case study of the Chicago open data project. Government Information Quarterly, 30(4), 508-513.

Klievink, B., Zuiderwijk, A., \& Janssen, M. (2014). Interconnecting Governments, Businesses and Citizens - A Comparison of Two Digital Infrastructures. Electronic Government, Springer Berlin Heidelberg, 84-95.

Kucera, J., Chlapek, D., \& Necasky, M. (2013). Open government data catalogs: Current approaches and quality perspective. Technology-enabled innovation for democracy, Government and governance, Lecture notes in computer science, 8061, 152-166. 
Kuk, G., \& Davies, T. (2011). The roles of agency and artifacts in assembling open data complementarities. In ICIS 2011: Proceedings 2011 International Conference on Information Systems. Shanghai, China.

Lee, J. H., Hancock, M. G., \& Hu, M. C. (2014). Towards an effective framework for building smart cities: Lessons from Seoul and San Francisco. Technological Forecasting and Social Change, 89, 80-99.

Levy, Y., \& Ellis, T. J. (2006). A systems approach to conduct an effective literature review in support of information systems research. Informing Science: International Journal of an Emerging Transdiscipline, 9(1), 181-212.

Lindman, J., Kinnari, T., \& Rossi, M. (2014). Industrial open data: Case studies of early open data entrepreneurs. In HICSS 2014: Proceedings of the $47^{\text {th }}$ Annual Hawaii International Conference on System Sciences. Waikoloa, Hawaii, USA.

Maccani, G., Donnellan, B., \& Helfert, M. (2015). Exploring the Factors that Influence the Diffusion of Open Data for New Service Development: an Interpretive Case Study. In ECIS 2015: Proceedings of 23rd European Conference on Information Systems. Münster, Germany.

Manyika, J., Chui, M., Groves, P., Farrell, D., Van Kuiken, S., \& Doshi, E. A. (2013). Open data: Unlocking innovation and performance with liquid information. McKinsey Global Institute. URL: http://www.mckinsey.com/business-functions/digital-mckinsey/our-insights/open-data-unlockinginnovation-and-performance-with-liquid-information (visited on: 12/05/2017).

Maruyama, M., Douglas, S., \& Robertson, S. (2013). “Design teams as change agents: Diplomatic design in the open data movement.” In HICSS 2013: Proceedings of the $46^{\text {th }}$ Annual Hawaii International Conference on System Sciences. Maui, Hawaii, USA.

Matheus, R., \& Janssen, M. (2016). Towards an ambidextrous government: Strategies for balancing exploration and exploitation in open government. In dg.o 2016: Proceedings of the 17th Annual International Conference on Digital Government Research. Shanghai, China.

Maturana, H., \& Varela, F.J. (1980). Autopoiesis and cognition: The realization of the living. London, Reidl.

Neuroni, A. C., Riedl, R., \& Brugger, J. (2013). Swiss Executive Authorities on Open Government Data-Policy Making beyond Transparency and Participation. In HICSS 2013: Proceedings of the $46^{\text {th }}$ Annual Hawaii International Conference on System Sciences. Maui, Hawaii, USA. 
Nonaka, I., \& Takeuchi, H. (1995). The knowledge-creating company: How Japanese companies create the dynamics of innovation. Oxford University Press.

O'Reilly, T. (2011). Government as a Platform. (Chap 2) In D. Lathrop \& L. Ruma (Eds), Open government: Collaboration, transparency, and participation in practice. O’Reilly Media.

Ojo, A., Curry, E., \& Zeleti, F. A. (2015). A Tale of Open Data Innovations in Five Smart Cities. In HICSS 2015: Proceedings of the $48^{\text {th }}$ Annual Hawaii International Conference on System Sciences. Kauai, Hawaii, USA.

Out of the box: The open data revolution has not lived up to expectations. But it is only getting started. (2015, November 21). The Economist. http://www.economist.com/news/international/21678833-open-data-revolution-has-not-lived-upexpectations-it-only-getting (visited on 05/02/2016).

Pollock, R. (2011) Building the (open) data ecosystem. URL: http://blog.okfn.org/2011/o3/31/buildingthe-open-data-ecosystem/ (visited on 12/05/2017).

Reggi, L., \& Dawes, S. (2016). Open government data ecosystems: Linking transparency for innovation with transparency for participation and accountability. Electronic Government. Springer International Publishing, 74-86.

Robinson, D., Yu, H., Zeller, W. P., \& Felten, E. W. (2008). Government data and the invisible hand. Yale Journal of Law and Technology, 11.

Rorty, R. (1980). Philosophy and the mirror of nature. Princeton University Press, Princeton, NJ.

Rudmark, D., Arnestrand, E., \& Avital, M. (2012). Crowdpushing: The flip side of crowdsourcing. In ECIS 2012: Proceedings of the Twentieth European Conference on Information Systems. Barcelona, Spain.

Scholl, H. J. J., \& Dwivedi, Y. K. (2014). Forums for electronic government scholars: Insights from a 2012/2013 study. Government Information Quarterly, 31(2), 229-242.

Skok, W. \& Kalmanovitch, C. (2005). Evaluating the role and effectiveness of an intranet in facilitating knowledge management: a case study at Surrey County Council. Information and Management, 42(5), 731-744.

Smith, G., Ofe, H.A., \& Sandberg, J. (2016). Digital service innovation from open data: Exploring the value proposition of an open data marketplace. 1277-1286. In HICSS 2016: Proceedings of the $49^{\text {th }}$ Annual Hawaii International Conference on System Sciences. Koloa, Kauai, Hawaii, USA. 
Styrin, E., Luna-Reyes, L.F., \& Harrison, T.M. (2016). Open data and open government: From abstract principles to institutionalized practices. In dg.o 2016: Proceedings of the 17th Annual International Conference on Digital Government Research. Shanghai, China.

Susha, I., Grönlund, Å., \& Janssen, M. (2015). Organizational measures to stimulate user engagement with open data. Transforming Government: People, Process and Policy, 9(2), 181-206.

Thorsby, J., Stowers, G.N.L., Wolslegel, K., \& Tumbuan, E. (2017). Understanding the content and features of open data portals in American cities. Government Information Quarterly, 34(1), 53-61.

Tilson, D., Lyytinen, K., Sørensen, C. (2010). Digital infrastructures: The missing IS research agenda. Information Systems Research, 21(4), 748-759.

Valja, M., \& Ladhe, T. (2015). Towards Smart City Marketplace at the Example of Stockholm. In HICSS 2015: Proceedings of the $48^{\text {th }}$ Annual Hawaii International Conference on System Sciences. Kauai, Hawaii, USA.

Van den Bergh, J., \& Viaene, S. (2016). Unveiling smart city implementation challenges: The case of Ghent. Information Polity: The International Journal of Government \& Democracy in the Information Age, 21(1), 5-19.

van Veenstra, A. F., \& van den Broek, T. A. (2013). Opening moves-drivers, enablers and barriers of open data in a semi-public organization. Electronic Government. Springer Berlin Heidelberg, 50-61.

Varela, F.J. (1992). Whence perceptual meaning? A cartography of current ideas. In: Varela, F.J., and Dupuy, J.P. (eds.) Understanding origins: Contemporary views on the origin of life, mind and society. Kluwer Academic Publishers, Dordrecht, 235-264.

Varela, F.J., Thompson, E., \& Rosch, E. (1992).The embodied mind. MIT Press. Cambridge, Mass.

Venzin, M., von Krogh, G., \& Roos, J. (1998). Future research into knowledge management. von Krogh, G., Kleine, D., and Roos, J. (eds.) Knowing in Firms: Understanding, Managing and Measuring Knowledge. Sage Publications, London, UK, p. 26

Von Krogh, G., \& Roos, J. (1995). Organizational Epistemology. St. Martin’s Press, 175 Fifth Avenue, New York, NY 10010.

Wareham, J., Fox, P. B., \& Cano Giner, J. L. (2014). Technology ecosystem governance. Organization Science, 25(4), 1195-1215. 
Webster, J., \& Watson, R. T. (2002). Analyzing the past to prepare for the future: Writing a literature review. MIS Quarterly, 26(2), 13-23.

Weick, K.E., \& Roberts, K.H. (1993). Collective mind in organizations: heedful interrelating on flight decks. Administrative Science Quarterly, 39, 357-381.

Zuiderwijk, A., Janssen, M., Choenni, S., Meijer, R., \& Alibaks, R.S. (2012a). Socio-technical impediments of open data. Electronic Journal of e-Government, 10(2), 156-172.

Zuiderwijk, A., Janssen, M., Meijer, R., Choenni, S., Charalabidis, Y., \& Jeffery, K. (2012b). Issues and guiding principles for opening governmental judicial research data. Electronic Government, Springer International Publishing, 90-101. 